\title{
CRISIS WITHOUT REVOLUTION : THE IDEOLOGICAL WATERSHED IN VICTORIAN ENGLAND
}

The English ruling classes under Queen Victoria prided themselves upon the dubious distinction that their suzerainty over three kingdoms was impervious to the upheavals that swept the European mainland. They at least had had the foresight to tame their monarchy with an oligarchy of wealth. "Your aristocracy and bourgeoisie ", Auguste Comte complained to an Oxford disciple in the 1850s, «... consider England wholly protected in advance against the present crisis of the West by their dynastic Revolution of 1688 " '. Subsequent events confirmed the safety of the ruling classes, although their sense of security was at least partly misplaced. Limited monarchies and reformed parliaments may fend off revolution, but not by virtue of their existence. Laws must be passed as deterrents, force must be used to stem unrest ; and in the "first industrial nation", where the manual working class was numerically dominant, the maintenance of public order also required a massive mobilization of consent. It did not take Elie Halévy to point out that Methodism helped prevent a revolution in the 1790s, however much his famous thesis has had to be qualified. Victorians themselves, who peered piously through the mists at republican France, fancied their isles a bastion of Christian civilization. Endemic evangelicalism and natural theology were proof to atheistic materialism. The salvos of « false philosophy " passed harmlessly through the religious atmosphere, like bullets through a fog. Ideologically, as well as institutionally, Victorian England lay shrouded in reaction to the causes and the consequences of the French Revolution.

The reaction was not static. Revolution remained more or less of a threat until 1848, with commensurate institutional responses ${ }^{2}$. By 1870 ,

1. Lettres d'A uguste Comte dे divers, Paris, 1902-1905, t. 1 (pt. 1), p. 313, quoted in Christopher KENT, Brains and Numbers : Elitism, Comtism, and Democracy in MidVictorian England, Toronto, University of Toronto Press, 1978, p. 99.

2. Malcolm I. THOMIS, Peter HoLT, Threats of Revolution in Britain, 1789-1848, London, Macmillan, 1977. 
however, one historical commentator announced that a "revolution " had indeed occurred. In a remarkable series of lectures entitled « The Revolution of the Last Quarter of a Century ", J. Baldwin Brown, a prominent dissenting clergyman, offered urbane reflections on the period of his ministry to a prosperous congregation in suburban London. He ascribed the revolution through which together they had passed to inflammatory intellectual events, notably in science and philosophy ; he also admonished his congregation that the social consequences of these events in the mid-nineteenth century required « an entire revolution in our ideas " . Likening the times to the fall of the Roman Empire, Baldwin Brown traced the demise of feudalism from its " deathwound $"$ in the French Revolution to the coup de grâce administered in 1846 by the advent of Free Trade. The weakness of the feudal system was its resistance to the world's " inevitable progress ", but its strength was « the definite order which it established in society ». Following its demise, " the social sorrow of our times, he declared, is that men do not know their places... All things are in constant flux » and men are filled with « distress and apprehension ${ }^{3}$.

« During these twenty-five years, the growth of a commercial civilization has widened the breaches and embittered the jealousies and enmities of society. So far from a new order springing up under the aegis of commerce, the world has seen, sadly enough, deepening disorder ; stern struggle and fierce hatred of classes ; gigantic armaments, tremendous wars, and universal distrust. The knowledge and intercourse which have attended the progress of our commerce, by means of cheap papers, cheap postage, railways, and telegraphs, have stimulated rather than allayed the internal discords and miseries of the great European nations " 4 .

England could escape the « social revolution » thus portended, according to Baldwin Brown, neither democratically, through universal suffrage, nor through " universal confiscation", the doctrine of the " extreme Reds", but only through " the rearrangement of the thoughts, feelings, and principles of individual human hearts ». English society required new divine sanctions for a moral order suited to its needs, even as the Augustinian effort to « justify the ways of God to man », with its feudal doctrines, had answered to the « remarkable crisis » of the Roman Empire in the fourth century. "The world ... is full of dark, sad difficulties ", Baldwin Brown concluded his final lecture ;

3. J. Baldwin Brown, First Principles of Ecclesiastical Truth : Essays on the Church and Society, London, Hodder and Stoughton, 1871, p. 244, 254, $272 \mathrm{ff}$.

4. Ibid., p. 283. 
" theodicies under any conditions are hard. " But the task of reconciliation is " the problem of the Church of the future " 5 .

Baldwin Brown's quarter-century of "revolution " was not the revolution England had feared, for a social revolution was precisely what, he urged, England could escape. Nor is his historical analysis beyond dispute. But as a contemporary witness, he calls attention instructively to a transitional period in English intellectual history, a period when the ruling classes experienced a " crisis " as they sought a new ideological framework - a new "theodicy " - for upholding industrial progress without revolution. The term " crisis ", like " revolution ", belongs primarily to the discourse of politics, economics, and social history. Baldwin Brown employed it in that context, as indeed have the editors of recent surveys, The European Crisis of the 1590s and The General Crisis of the Seventeenth Century ${ }^{6}$. Conventionally, however, the only crisis to interest intellectual historiaiss of Victorian England has been a " crisis of faith ": a spiritual condition of bourgeois thinkers beset by religious doubt in the years around 1859. Only recently have historians begun to explore the wider crisis delineated by Baldwin Brown. By tracing these historiographic developments this essay aims to conceptualize the wider crisis as a thesis in the social history of ideas and to show how it may be viewed as an ideological watershed in English religious thought.

The translation in 1953 of Paul Hazard's La Crise de la conscience européenne (1935) under the title The European Mind, 1680-1715 indicates the manner in which English-speaking intellectual historians a generation ago were accustomed to deal with the concept of crisis. Hazard of course concerned himself with « les grands changements psychologiques ", a richer subject than the ideas studied magisterially by A. O. Lovejoy and his American successors since the 1930s ; and in some respects works such as Perry Miller's The New England Mind (1939-1953) and Henry Steele Commager's The American Mind (1950) were worthy to stand beside Hazard's. Walter Houghton's The Victorian Frame of Mind (1957) must also be mentioned, a seminal work that put «Victorian Studies» on the academic map. Houghton, however,

5. Ibid., p. 286-289, $345 \mathrm{ff}, 364$.

6. Peter Clark, ed., The European Crisis of the 1590s : Essays in Comparative History, London, George Allen \& Unwin, 1985 ; Geoffrey PARKER, Lesley M. SMITH, eds, The General Crisis of the Seventeenth Century, London, Routledge \& Kegan Paul, 1985. 
like other historians who have taken the human " mind » as their subject, sometimes assumed too readily that minds in the past were accessible, that periods as well as persons had minds, and that the minds of persons in a period were more or less undifferentiated. (" The working class, he admits, is not here under consideration ».) More seriously, there is the wholesale neglect of the " hardware » of history, the material conditions of intellectual change, as measured by the 430 pages that Houghton devotes to " emotional », " intellectual », and " moral attitudes " as set against five initial pages on " the state of society " ?.

The Victorian crisis has attracted idealist interpretations on these lines for a very long time. In 1934 an elderly Victorian reminisced that the " one fundamental cause of the confusion and conflict... was the opposition between what may be termed the static and dynamic conceptions of Reality as a whole ${ }^{8}{ }^{8}$. Even fifty years later it sometimes seems as if nothing less nebulous has congealed. "More was involved... than natural selection and evolution ", according to a recent essay on intellectual developments. « Underlying the change... was a more fundamental and gradual change of mind". The article goes on to point out that "ideas do not exist of themselves. They have to be thought ; they are the creations of human minds ". Thus, " the Victorian crisis of faith was in significant part, a creation of the Victorians themselves $"$. One had really never been in much doubt about the matter, although it is only fair to acknowledge that idealist historiography has also dealt more profoundly with the Victorian cognitive crisis ${ }^{9}$.

In an essay entitled « Science, Religion, and the Critical Mind », Noel Annan explains that the crisis resulted from the influence of a « powerful intellectual movement ". " Positivism, he says, called the tune and forced other modes of thought to dance to it ". After the publication of the Origin of Species in 1859, positivism entered a new phase and brought about the " secularization of intellectual life " ${ }^{10}$. Diametrically opposed to this view is the revisionist proposal of Josef Altholz that the crisis of faith was " a crisis within religion itself ". The " mind of Victorian orthodoxy " had ossified : it knew only rationalistic self-defence ;

7. Walter E. Houghton, The Victorian Frame of Mind, New Haven (CT), Yale University Press, 1957.

8. J. Scott LIDGETT, The Victorian Transformation of Theology..., London, Epworth Press, 1934, p. 21.

9. D. H. MEYER, "American Intellectuals and the Victorian Crisis of Faith ", in Daniel Walker Howe, ed., Victorian America, Philadelphia, University of Pennsylvania Press, 1976, p. 62, 75.

10. Noel ANNAN, "Science, Religion, and the Critical Mind : Introduction ", in Philip APPLEMAN et al., eds, 1859 : Entering an Age of Crisis, Bloomington, Indiana University Press, 1959, p. 32, 34, 37. 
it was unable to " enter into a creative dialogue with... new ideas ". Sensitive religious souls therefore experienced a « warfare of conscience with theology " ${ }^{11}$. Altholz's proposal has certain advantages, not least that it transcends the old dualism of " science versus theology " and suggests the element of moral crisis. But one would be hard pressed to demarcate religious ideas from others or to show that orthodoxy - even Anglican orthodoxy - shared a single " mind". More to the point : although, admittedly, evangelical doctrines and humanitarian values were " bound to come into conflict ", the fact remains that this occured on a wide scale, and quite dramatically, at a particular place and time. Why in mid-Victorian Britain ? If, according to Annan's analysis, there was more to be truthful about just there and then - geology, German theology, and so forth - was there not also more to be moral about ? Or are truth and morality to be divorced in treatments of the period? The cross-examination of these historians might be conducted at any length, but instead one may offer the remark of a contemporary as a coda to the long and honourable series of attempts to treat the Victorian crisis as pre-eminently an intellectual phenomenon : " Everything which sets men in motion must go through their minds, wrote Engels, but what form it will take in the mind will depend very much upon the circumstances $\gg 12$.

Engels' remark need not be read as a call for historiographic revolution. It is quite compatible with a kind of intellectual history that gives pride of place to ideas within their social context. In recent years several such works have appeared that promote a reassessment of the conventional « crisis of faith ». Ironically, they constitute a self-styled « revolutionary » tradition. Ellen Frankel Paul has described a « moral revolution " in nineteenth-century British political economy ; Martin Wiener has traced a "counterrevolution of values " in mid-Victorian English culture. According to Paul, the moral revolution coincided roughly with the career of John Stuart Mill, whose Principles of Political Economy (1848) stemmed the tide of laissez-faire with a radical doctrine of utility that Mill had adopted under pressure from the " growing anti-individualistic agitation of the times ". Political economy thereafter became a respectable academic science dissociated from a particular economic and social system. "All extraneous moral and political consi-

11. Josef L. ALtholz, "The Warfare of Conscience with Theology ", in ID., ed., The Mind and Art of Victorian England, Minneapolis, University of Minnesota Press, 1976, p. 58-85 ; ID., " The Mind of Victorian Orthodoxy : Anglican Responses to "Essays and Reviews", 1860-64 ", Church History, t. 51, 1982, p. 186-197.

12. F. ENGELS, "Ludwig Feuerbach and the End of Classical German Philosophy ", in Karl MARX, Frederick Engels, On Religion, London, Lawrence \& Wishart, 1957, p. 255. 
derations " were supposed to have been " expunged " 13. This " demise " of laissez-faire as a result of « moral and political upheavals ", instead of "alterations in pure economic theory », sounds rather like the blow to the English « industrial spirit » that Wiener ascribes to a " counterrevolution of values". After the " high noon of British technological leadership " at the Great Exhibition of 1851, he states, the sun began to set rapidly on British industry. It was the deaths of three giants of British engineering - Brunel, Stephenson, and Joseph Locke - within months of each other in 1859-1860 that « heralded the end of an era $»$. Their achievements were soon overtaken by cultural critics - Mill, Ruskin, Dickens, and Matthew Arnold - whose

" ideas shaped and were themselves part of a conservative revolution in mid- and late-Victorian England that contained the social and intellectual consequences of the industrial revolution. A traditional elite adapted sufficiently to the new circumstances and demands of the age to ward off pressure for a truly thorough upheaval ${ }^{14}$.

It is noteworthy that Wiener's counter-revolutionary point de départ coincides with social events that took place about 1859. Howard Mumford Jones once suggested that if we must seek a crisis beginning in that year, we should not look to Darwin and the Origin of Species, but to a middled-aged man boring holes in the ground at Titusville, Pennsylvania. On August 27th he struck oil at its source, at a depth of sixty-nine feet, and proved for the first time the existence of reservoirs of petroleum within the surface of the earth ${ }^{15}$. This suggestion, which deflects attention from a solemn event in intellectual history, would probably find favour with the author of Darwin and the Darwinian Revolution (1959), whose approach to her sacrosanct subject incurred the wrath of the evolutionary establishment. Darwin, according to Gertrude Himmelfarb, only seldom provoked a crisis of faith. Instead the Origin of Species served to legitimate what many people already believed. The Darwinian Revolution was a " conservative revolution », for it extended, stabilized, and ratified certain tendencies that had been present in English culture since the scientific revolution of the seventeenth century.

13. Ellen Frankel Paul, Moral Revolution and Economic Science : The Demise of Laissez-Faire in Nineteenth-Century British Political Economy, Westport (CT), Greenwood Press, 1979, p. 208-209.

14. Martin J. WIENER, English Culture and the Decline of the Industrial Spirit, Cambridge, Cambridge University Press, 1981, p. 29-31, 40.

15. Howard Mumford JONES, " 1859 and the Idea of Crisis : General Introduction ", in P. APPLEMAN et al., eds, op. cit. supra n. 10, p. 28. 
"Science became the business of man when man became the business of science : when Watt applied himself to the invention of the steam engine and Darwin to the ancestry of mankind. Only then were the technology and mechanism implicit in the earlier revolution finally unleashed and the old humanistic order swept away ${ }^{16}$.

There is much truth in Himmelfarb's assessment, despite, one fears, a certain hankering after " the world we have lost " ${ }^{17}$. From it the real dimensions of the crisis through which the Victorians passed may be inferred, although it must be added that, on conventional accounts, reality and appearance do not coincide. For example, Kitson Clark has pointed out that a large sector of the British populace seems to have experienced the years immediately after 1859 , « not as years of an acute crisis of mind but rather as the years of the great religious revivals ". Such people were scarcely troubled by Darwin and they certainly never read the notorious Broad Church manifesto published in 1860, Essays and Reviews ${ }^{18}$. Those who experienced the mental crisis, both before and after 1859, were typically men-of-letters and middle-class intellectuals, people with learning and leisure on their side. To discover the reality of a larger crisis that touched the life of all one must therefore look beyond their mental distress to its objective counterpart in the contradictions and dilemmas of an industrial society edging towards reform. In so far as " revolutionary » intellectual history has contributed to this broader view of the Victorian crisis by juxtaposing ideas with their social contexts, it has done good service. But in recent years historians have been looking at the subject more critically.

It is hazardous to generalize about the tendencies of work-inprogress, particularly when it is that of many colleagues. Nevertheless among historians who have reached scholarly maturity in the past twenty years there now seems to be a growing presumption that conven-

16. Gertrude Himmelfarb, Darwin and the Darwinian Revolution, reprint ed., New York, W.W. Norton \& Co., 1968, p. 447-452. A full discussion of the « Darwinian Revolution " metaphor is long overdue. The best treatment to date is in John C. GREENE, "The Kuhnian Paradigm and the Darwinian Revolution in Natural History ", Science, Ideology, and World View : Essays in the History of Evolutionary Ideas, Berkeley, University of California Press, 1981, p. 30-59.

17. No such hankering appears in Himmelfarb's latest, splendid work, The Idea of Poverty : England in the Early Industrial Age, London, Faber \& Faber, 1984.

18. G. Kitson ClARK, The Making of Victorian England, London, Methuen \& Co., University Paperbacks, 1965, p. 147-148. 
tional interpretations of the Victorian " crisis of faith " must be enlarged. According to these scholars, many of whom are historians of science, the crisis has been caricatured, firstly, through assimilation to the notorious historiography of a " conflict " or " warfare " between Victorian religion and science. This positivist or "whig " historiography, in which science always triumphantly " wins.", was the product of an era when positive science was winning, by virtue of its tangible results, the cultural status formerly enjoyed by religion. That era, however, has long passed, and with it the " military metaphor " as a plausible device in intellectual history ${ }^{19}$. Secondly, the idealist historiography discussed earlier, which was codified by philosopher-historians such as Lovejoy in America and R. G. Collingwood in England, became a dominant approach to the Victorian crisis in the decades since 1930, when the liberal intellectual heritage that had fostered scientific progress was seen to be under attack by totalitarianisms of the left and right. That era, too, for many intellectual historians has also passed, and with it interpretations that deal primarily in disincarnate minds. For in the last forty years the tangible results of scientific progress, East and West, have been seen as contributions to, not casualties of, totalitarian threats. With the rise of a radical critique of liberal technocracy in the 1960s and the expansion of academic programmes in " science and society ", numerous younger historians began seeking a new historiography that would be neither positivistic nor idealistic, but frankly critical of the origins and the tendencies of modern scientific rationality. Many who now concern themselves with Victorian intellectual history have endeavoured to trace the social filiations and ideological consequences of beliefs and values, regardless of their putative " religious " or « scientific » status. How far their views differ from the assumptions of older interpreters of the period may be judged from a remark made in 1959 by Asa Briggs concerning the last decades of the nineteenth century : "The conflict between science and religion petered out, giving way to new debates about the nature not of the Universe but of society $"{ }^{20}$. Few if any historians writing today could assume with impunity that the earlier " debates about the nature... of the Universe " were any less debates about society than the latter.

For this larger understanding historians are indebted to works such as

19. See James R. MOORE, The Post-Darwinian Controversies : A Study of the Protestant Struggle to come to terms with Darwin in Great Britain and America, 1870-1900, Cambridge, Cambridge University Press, 1979, pt. 1.

20. Asa BriGGs, The Age of Improvement, 1783-1867, reprint ed., London, Longmans, 1963, p. 488. 
T. W. Heyck's The Transformation of Intellectual Life in Victorian England (1982). Avoiding the metaphor of revolution, Heyck sets out to analyse inter alia « the precise mental and material mechanisms by which Victorian culture - or at least high culture - was connected to social change ". He concentrates on the emergence of " intellectuals " as a distinct social group, and this leads him to consider the "Victorian religious crisis " that, he says, affected « educated people » after 1860. The crisis was a many-factored thing, but the " conflict between science and theology " played a very large part in it, not least by damaging the " umbrella of natural theology " that had served as " the "common context" of public discourse in England ". The conflict between science and theology was itself, however, " part of that very complex phenomenon known as the decline of religion or the secularization of thought ", for which a sociological explanation is " in large part " required if the beliefs of the general public are to be taken into account 21 . Whether such explanations may be extended to the scientific beliefs of the intelligentsia is not clear. Heyck is more interested in the " impact of science $"$ than in the social significance of its doctrines. On this latter point one must consult a historian who has viewed the " conflict between science and religion " as an episode in the social history of ideas.

Frank Turner, who has published several important monographs on the subject, argues that the Victorian conflict occurred between preprofessional and professionalizing groups within scientific institutions and between established and emerging professional élites within the broader culture. The dramatis personae in both cases were the same : clerical or clerically-educated leaders, on the one hand, who subscribed traditional creeds and held that scientific research should stand « subordinate to moral values, a concept of God, and a view of human nature " derived from natural and supernatural revelation ; and, on the other hand, middle-class intellectuals who adhered to the doctrines of « scientific naturalism " and maintained that scientific research should be pursued " without regard for religious dogma, natural theology, or the opinions of religious authorities ». These insurgent intellectuals, « by claiming their own epistemology as the exclusive foundation for legitimate science and as the correct model for knowledge generally, ... sought to undermine the intellectual legitimacy of alternative modes of scientific thought and practice $»$. But Turner contends that the conflict they provoked was « more than a dispute over ideas ». " It manifested the tension arising as the intellectual nation became more highly differentiated

21. T. W. HEYcK, The Transformation of Intellectual Life in Victorian England, London, Croom Helm, 1982, p. 17, 83-86. 
in functions, professions, and institutions ». It was a contest for " popular cultural preeminence in a modern industrial society " 22 .

Turner and Heyck place the Victorian crisis of faith in the established contexts of " secularization " and " professionalization "; they connect it with familiar research on the role of intellectuals and the rise of naturalistic beliefs. But numerous questions remain. For example, how precisely did the ideas of intellectuals articulate with their social roles and affiliations ? Where did the doctrines of scientific naturalism originate, and why did they prevail ? Did scientific naturalism simply furnish intellectuals with an arsenal of " ideological weapons " ${ }^{23}$, or were naturalistic ideas related more organically to social and religious traditions ? If so, to what extent was there already a basis of appeal in English culture for crisis-stricken individuals in their bid to gain ascendancy within the intelligentsia ? Not one of these questions can even be posed, let alone answered, convincingly in the space available here. But other practitioners of the social history of ideas have furnished relevant insights by the manner in which they have dealt with Victorian ideological debates.

Robert Gray has analysed the shifting relations of economic power and ideological leadership in nineteenth-century Britain by using the conceptual apparatus of Antonio Gramsci. In an article entitled « Bourgeois Hegemony in Victorian Britain ", Gray proposes that in the second quarter of the century the " power bloc " of allied dominant classes experienced an « organic crisis » because it failed not only to represent newly important fractions of the bourgeoisie, such as industrial capital, but to mobilize the consent of the lower strata and their newer fractions. The 1832 Reform Act, Owenism, Chartism, and the « labour aristocracy » immediately spring to mind. The crisis was resolved in the third quarter of the century with the stabilization and diversification of the economy. The power bloc that emerged in this period incorporated the new owners of wealth; the industrial bourgeoisie within the power bloc constituted its « hegemonic fraction ". Their leadership, says Gray, was exerted chiefly through an « urban gentry » of

22. Frank M. TURner, " The Victorian Conflict between Science and Religion : A Professional Dimension ", Isis, t. 69, 1978, p. 361, 364 ; ID., " Rainfall, Plagues, and the Prince of Wales : A Chapter in the Conflict between Religion and Science ", Journal of British Studies, t. 13, 1974, p. 65. See also ID., Between Science and Religion : The Reaction to Scientific Naturalism in Late Victorian England, New Haven (CT), Yale University Press, 1974, chap. 1 and ID., "Victorian Scientific Naturalism and Thomas Carlyle ", Victorian Studies, t. 18, 1974-1975, p. 325-343.

23. ID., "John Tyndall and Victorian Scientific Naturalism ", in W. H. BRock et al., eds, John Tyndall: Essays on a Natural Philosopher, Dublin, Royal Dublin Society, 1981, p. 174. 
bourgeois intellectuals who organized consent and contained dissent among the lower classes by propagating " an ideology common to the ruling class as a whole, but also with certain traits specific to the urban gentry ". Of course this " hegemonic ideology had differentiated versions and interpretations, and was constantly argued out and reformulated within the ruling class ». But throughout its forms it carried an " evangelistic " ethos, " in both a specifically religious and general metaphorical sense of the term ", and a meliorist bias towards reforming individual behaviour among the working classes through correct teaching about the " laws" of the social environment.

« Economic, moral and religious concerns were fused into a single image of urban social danger ; iron laws, whether of calvinist theology or classical economics, dictated discipline and restraint, the slightest backsliding would lead to disaster, and individual weakness could spread contagiously to demoralize society and reverse the precarious conquest of scarcity achieved through industriousness and foresight $" 24$.

Gray, like Heyck and many other social historians, does not bring the alleged scientificity of these teachings within the purview of his analysis. But he helps to contextuate Turner's hegemonic struggle over professionalization and offers a more radical view of the issues at stake in the rise of scientific naturalism.

Ideological issues also figure prominently in the work of a historian who complements Gray's analysis with a wide-ranging discussion of the nineteenth-century debate over " man's place in nature ". In the first of three seminal articles, now recently reprinted ${ }^{25}$, Robert $M$. Young argues that the rich interdisciplinary culture that prevailed through midcentury as the setting of the debate among the British intelligentsia fragmented during the 1870s into " specialist careers, societies and publications ", in part because of the "impact of scientific findings" on a " coherent natural theology » that had played an « important integrative function " in the old interdisciplinary " common context " of debate ${ }^{26}$. In his second article Young makes the point that the contro-

24. Robert GRAY, « Bourgeois Hegemony in Victorian Britain ", in Jon Bloomfield, ed., The Communist University of London: Papers on Class, Hegemony, and Party, London, Lawrence \& Wishart, 1977, p. 85.

25. Robert M. YounG, Darwin's Metaphor : Nature's Place in Victorian Culture, Cambridge, Cambridge University Press, 1985.

26. ID., " Natural Theology, Victorian Periodicals, and the Fragmentation of a Common Context ", in Colin Chant, John Fauvel, eds, Darwin to Einstein : Historical Studies on Science and Belief, London, Longman/Open University Press, 1980, p. 69-107. Young's article is the source of Heyck's reference to " the "common context" " in the text supra at n. 21. 
versy over Darwin's contribution to the debate was « seen by its participants as occurring within natural theology, with no antitheistic overtones "; the controversy, in which " a desire for conflict was not an important motive », produced « an adjustment within a basically theistic view of nature " and gave rise to a « secular religion of Progress ». Finally, Young's third article looks beyond the fragmentation of an intellectual " common context ", with the transformation of natural theology, in the debate over man's place in nature, to the « social, political, and ideological " significance of the debate itself. Although at one level the debate can be seen as a controversy between science and theology, writes Young,

" at another level the protagonists... were in fundamental agreement. They were fighting over the best ways of rationalizing the same set of assumptions about the existing order. An explicitly theological theodicy was being challenged by a secular one based on biological conceptions and the fundamental assumption of the uniformity of nature $"{ }^{27}$.

Young employs the term "theodicy " in approximately the same sense that Baldwin Brown used it a century before. This marks a significant breakthrough in understanding whatever one may wish to call the "Victorian crisis », although Young's analyses have not been found invulnerable at every point. It is now known, for example, that natural theology in the early nineteenth century was not a " coherent » endeavour. Great fissures have recently been opened in the solid front that historians once presumed existed among pre-Darwinian naturalists. These naturalists, it appears, disagreed sometimes quite fundamentally about the correct theological interpretation of animal instincts, patterns of organic adaptation, the geological column, the plurality of worlds, and the nebular hypothesis ${ }^{28}$. Natural theology was in trouble long

27. R. M. Young, "The Impact of Darwin on Conventional Thought ", in John SYMONDSON, ed., The Victorian Crisis of Faith : Six Lectures..., London, SPCK, 1970, p. 13-35 ; ID., " The Historiographic and Ideological Contexts of the Nineteenth-Century Debate on Man's Place in Nature ", in Mikuláś TEICH, R. Young, eds, Changing Perspectives in the History of Science : Essays in Honour of Joseph Needham, London, Heinemann, 1973, p. 344-438.

28. Robert J. RichARDS, « Instinct and Intelligence in British Natural Theology : Some Contributions to Darwin's Theory of the Evolution of Behavior ", Journal of the History of Biology, t. 14, 1981, p. 193-230 ; Dov OsPovat, « Perfect Adaptation and Teleological Explanation : Approaches to the Problem of the History of Life in the Mid-nineteenth Century ", Studies in History of Biology, t. 2, 1978, p. 33-56 ; John Hedley BroOKE, "The Natural Theology of the Geologists : Some Theological Strata ", in L. J. JoRDANOVA, Roy S. PORTER, eds, Images of the Earth : Essays in the History of the Environmental Sciences, Chalfont St. Giles (Bucks, UK), British Society for the History of Science, 1979, p. 39-64 ; ID., « Natural Theology and the Plurality of Worlds : Observa- 
before 1859 , and it would be almost as wrong to believe that its cohesive force was broken only in the 1870s, with the fragmentation of Young's " common context " of intellectual discourse, as it would be to agree with Susan Cannon that in the same period Darwin " shattered " an over-arching theistic « Truth-Complex » and gave rise to C. P. Snow's « two cultures » 29 .

It also now appears, thanks to Turner, that the " desire for conflict » in the controversy over Darwinism was indeed an " important motive ", not, as Young says, the reverse. "Conflict " was felt to be both the moral obligation and the sad recompense of those who undertook the aggrandizement and professionalization of science. "Under the circumstances of the time ", T. H. Huxley remarked in 1888 to a comradein-arms, « warfare has been my business and duty " ${ }^{30}$. Furthermore, if one looks beneath the gaudy veneer of " war " and allows Young's view that $"$ at another level the protagonists... were in fundamental agreement », it seems unlikely that the subject of agreement was always what Young calls a " set of assumptions » about the existing social order. Huxley, again, had no truck with feudalism among his opponents, whether in the form of romantic Anglo-Catholicism or as a tendency in the Positivist « Religion of Humanity ". Of course the protagonists may sometimes have agreed on a set of assumptions about the existing order ; but they did always agree on the assumption that people ought to accept as given or inevitable, and therefore be reconciled to, one or another social arrangement. The grounds for justifying this assumption may have been the will of God, or the course of Nature, or both. The grounds were often disputed ; or, as Gray puts it, « hegemonic ideology... was constantly argued out and reformulated within the ruling class ". Thus arose the theodicies referred to by Young and Baldwin Brown : coherent accounts of the world that effectively reconciled people to society in some particular form.

"An interpretation must be worked out, Young suggests, which stresses the development from one theodicy - in both its scientific and social aspects - to another. The first was suitable for a relatively static and rural economy while the other was developed for a rapidly-changing and industrializing society $"{ }^{31}$.

tions on the Brewster-Whewell Debate ", Annals of Science, t. 34, 1977, p. 221-286 ; ID., "Nebular Contraction and the Expansion of Naturalism ", British Journal for the History of Science, t. 12, 1979, p. 200-211.

29. Susan Faye CANNON, Science in Culture : The Early-Victorian Period, New York, Dawson/Science History Publications, 1978, chap. 9.

30. T. H. Huxley to E. R. Lankester, 6 December 1888, in Leonard HuXLEY, Life and Letters of Thomes Henry Huxley, London, Macmillan and Co., 1900, t. 2, p. 213.

31. R. M. YounG, "The Historiographic... ", art. cit. supra n. 27, p. 384. This latter 
" Theodicy ", " natural theology ", « common context ", « power bloc ", " hegemonic ideology ", "professionalization ", " secularization $":$ where is the broader perspective on the Victorian crisis of faith among this tangle of terms used by intellectual historians in the last twenty years? In the light of the work of Young and Gray, Turner and Heyck, it would appear that scholarship has arrived by a circuitous route at conclusions about a Victorian crisis that in certain respects resemble the contemporary analysis of Baldwin Brown. Along the way idealist interpretations of the Victorian crisis have been set aside, although "revolutionary " intellectual history has provided limited support for the broader view that the crisis was a culture-wide phenomenon rooted in the basic tendencies of an industrializing society. This broader view may now be stated provisionally as a thesis in the social history of ideas.

The Victorian crisis was not merely a crisis of faith. Faith (or belief) was the corollary of action, and action based on faith embodied social purpose. The crisis was a crisis of legitimation. Among the Victorian intelligentsia the crisis arose from the necessity laid upon them of prescribing purposive action, or practical measures, for dealing with social conflict in a manner consistent with securing their own status and emoluments in a diversifying economy. The crisis for the rest of society lay in the social conflicts themselves, arising chiefly from economic change, or in the flux of bourgeois opinion, which tended to undermine personal meaning and coherence. Bourgeois opinion was convulsed by the intelligentsia as they offered competing social prescriptions, or competing raisons d'être for closely similar prescriptions, before the general public. Their internecine conflicts may be seen as ideological struggles in so far as the points at issue were the ultimate beliefs from which social prescriptions were held to flow. The same internecine conflicts may be seen equally as political struggles in so far as the authority of the respective

criticism addresses the deficiencies in Young's interpretation that Young himself acknowledges at notes 93,114 , and 120 of his text. On the movements of political radicalism and reform that he neglects, see J. R. MOORE, « 1859 and All That : Remaking the Story of Evolution-and-Religion ", in Roger ChAPMAN, Cleveland T. Duval, eds, Charles Darwin, 1809-1882: A Centennial Commemorative, Wellington (NZ), Nova Pacifica, 1982, p. 167-194. On the wider use of " theodicy ", see A. JÄGER, "Theodizee und Anthropodizee bei Karl Marx ", Schweizerische Theologische Umschau, t. 37, 1967, p. 14-23 ; Ernest BECKER, The Structure of Evil : An Essay on the Unification of the Science of Man, New York, George Braziller, 1968 ; Richard KENNINGTON, " Descartes and Mastery of Nature ", in Stuart F. SPICKER, ed., Organism, Medicine, and Metaphysics : Essays in Honor of Hans Jonas..., Dordrecht, D. Reidel Publishing Co., 1978, p. 201-223 ; and Kenneth SURIN, "Theodicy? ", Harvard Theological Review, t. 76, 1983, p. 225-247. 
parties was at stake, and thus the power of each to shape opinion and events. "Professionalization ", the institutionalizing and canonizing of independent expertise, was the high road to power and authority among bourgeois intellectuals. "Secularization ", the marginalizing and usurping of power and authority, was the back door for sectors of the intelligentsia who lost out in the political and ideological debate. The Victorian crisis culminated in the professionalization of science, in this sense, and in the secularization of religion. But the relationship was not simply one of cause and effect, as the juxtaposition might suggest. For religious faith was almost never attacked merely for its own sake by the adherents of scientific naturalism. Rather, these intellectuals saw their struggles with established authority " as a means of freeing that faith for what were regarded as being nobler and more adequate forms in which it could find expression $" 32$.

Thus the crisis of the intelligentsia did not consist solely of personal spiritual angst, nor was it so simple as a "conflict of religion and science ". Whatever its manifestations may have been - personal or institutional, political or ideological - the crisis must be referred to the wider struggle to negotiate new doctrines, new beliefs, new forms of consent that would be seen to maintain continuity with and fulfil the best aspirations of older creeds but, at the same time, would serve to order and stabilize class relations more effectively by allowing for new patterns of expectation in a liberalizing and " improving " society. This process of negotiating what amounted to a new theodicy may be seen as part of the " naturalization " of religion ${ }^{33}$. If secularization was the removing of religious ideas, religious values, and religious institutions with their professional representatives from positions of power and authority in national life, then naturalization meant the transforming of these ideas, values, and institutions so that the equivalent religious power and authority became vested in natural ideas, naturalistic values, and institutions led by professional interpreters of nature. In this

32. Maurice Mandelbaum, History, Man, and Reason: A Study in NineteenthCentury Thought, Baltimore (MD), Johns Hopkins Press, 1971, p. 30.

33. See Vernon PraTt, Religion and Secularisation, London, Macmillan and Co., 1970 , p. $13 \mathrm{ff}$; R. M. Young, "The Naturalization of Value Systems in the Human Sciences ", in Michael BARTHOLomew et al., Problems in the Biological and Human Sciences, Milton Keynes (UK), Open University Press, 1981, p. 63-110; and J. R. MOORE, « Evangelicals and Evolution : Henry Drummond, Herbert Spencer, and the Naturalization of the Spiritual World ", Scottish Journal of Theology, t. 38, 1985, p. 383-417. Compatible conclusions have been reached in Edward RoYLE, Radicals, Secularists, and Republicans : Popular Freethought in Britain, 1866-1915, Manchester, Manchester University Press, 1980, p. 329 and Sheridan Gilley, Ann LOADES, « Thomas Henry Huxley: The War between Science and Religion ", Journal of Religion, t. 61, 1981 , p. 289. 
process the locus of the sacral moved from the noumenal towards the phenomenal, from the eternal towards the temporal, from another world towards this world. Naturalization thus became the actual expression of " meliorism ", the contemporary term that perhaps best indicates the real dimensions of the Victorian crisis ${ }^{34}$.

The Victorian naturalization of religion proffered a new theodicy justifying social relationships, not in the manner of the old theodicy, as providential dispensations to be recompensed in a future life, but as the by-products of an immanent progressive order that promised material salvation through moral achievement in history. This theodicy formed the ideological resolution of the Victorian crisis and, as such, marked a profound transformation, not only in intellectual culture, but throughout English society. The ideological watershed fell in the quarter century reviewed by Baldwin Brown, and, clearly, historical literature already contains important studies of the debates and protracted negotiations of this period - indeed, from 1840, when John Sterling declared the " necessity for a great crisis in the belief of England » until well after James Martineau's assessment in 1864 that « the present crisis of faith is deeper and wider than any since the Reformation " ${ }^{35}$. Recently the making of a new naturalistic theodicy has been seen as the work of dissident intellectuals such as the agnostics Herbert Spencer, T. H. Huxley, and Leslie Stephen, the positivists Frederic Harrison, George Lewes, and John Morley, and the liberal theists Francis Newman and James Anthony Froude, aided and abetted to some extent by Broad Churchmen such as F. D. Maurice, A. P. Stanley, and J. W. Colenso. These were " the leaders of... intellectual progress " with whom liberal clergymen like Baldwin Brown sought " common ground ", but it has not been customary, then or now, to view Victorian intellectuals en bloc as allies of religion, let alone as exponents of a new theodicy. In conclusion, therefore, it will be useful to indicate how the dissident intellectuals themselves interpreted the ideological watershed of their times in overtly religious terms. To them " new doctrines " based on « new revelations " were creating a " new faith » that would proclaim a « new gospel " for a new social order ${ }^{36}$. A revolution was by no means in progress, but a « New Reformation ».

34. See Jane Hume ClAPPERTON, Scientific Meliorism and the Evolution of Happiness, London, Kegan Paul, Trench \& Co., 1885.

35. Sterling, quoted in Olive Brose, «F. D. Maurice and the Victorian Crisis of Belief ", Victorian Studies, t. 3, 1959-1960, p. 230 ; James Martineau, Essays, Reviews, and Addresses, London, Longmans, Green, and Co., 1891, t. 2, p. 464.

36. J. B. Brown, op. cit. supra n. 3, p. 250. For the latter references and the fuller discussion from which the following pages are adapted, see J. R. MOORE, "Theodicy and 
The slogan, a " New Reformation ", contained both a taunt and a truth. As controversialists, the dissident intellectuals took every opportunity to point up the ironies of the Church's position in relation to their own. Spencer argued that the dependence of sociology on biology was evident from the First Book of Richard Hooker's Laws of Ecclesiastical Polity, the great Elizabethan apologia of the English Church. Hooker's view of individuals in society, he stated, " needs but better definition and further development to make it truly scientific $"{ }^{37}$. Huxley stressed on various occasions that his own objectionable views were consistent with, or at least theologically no more controversial than, the teachings of Augustine, Erasmus, Calvin, and Bishop Butler. Moreover, Huxley did not begrudge that the Anglican Church as an institution was « a great and powerful instrument for good or evil ». So engagingly, indeed, did he once describe " an Established Church which should be a blessing to the community ", one which " no one would seek to disestablish ", that an Anglican colleague was pleased to remark that the Church of Huxley did not differ greatly from " the Church of Arnold and Maurice, Kingsley and Jowett $"{ }^{38}$. It was perhaps this ambivalence about the Established Church - a coveting of its power and authority coupled with a loathing for its creed, an inclination to reform the institution tempered by an impulse to abolish it - that made the Protestant Reformation a potent metaphor for the dissident intellectuals. For the truth in their slogan, a New Reformation, was that they saw their new religion maintaining continuity with the old ; the taunt was that they believed the new religion must be born by means of an intellectual and social transformation not unlike the one in which the Anglican Church had emerged from the Church of Rome ${ }^{39}$.

The proximate source of the slogan may have been the phrenologist George Combe, who had written as early as 1847 of a "Second Reformation " to be brought about in Britain through public education in the

Society : The Crisis of the Intelligentsia ", in Richard HELMSTADTER, Bernard V. LiGHTMAN, eds, Victorian Faith in Crisis, Montreal, McGill-Queens University Press, forthcoming.

37. Herbert SPENCER, The Study of Sociology, reprint ed., London, Kegan Paul, Trench \& Co., 1889, p. 327.

38. T. H. Huxley to C. Kingsley, 23 Sept. 1860, in L. HuXLEY, op. cit. supra n. 30, t. 1, p. 221 ; Thomas Henry HuXLeY, Collected Essays, London, Macmillan and Co., 1893-1894, t. 1, p. 284 ; John LubBock, The Use of Life, London, Macmillan and Co., 1894, p. 223.

39. See A. O. J. Cockshut, Anglican Attitudes : A Study of Victorian Religious Controversies, London, Collins, 1959, chap. 2. 
principles of naturalistic morality ${ }^{40}$. In 1853 Froude adumbrated the slogan in an article on the Book of Job. "The whole question of life and its obligations, he said, must again be opened " as it was " some three centuries " ago in the Protestant struggle with immorality and superstition. To Froude the Reformation was the hinge of modern history. The first four volumes of his History of England, completed by 1858 , contained an impassioned plea for its principles in the context of an argument for English liberty and freedom of thought ${ }^{41}$. In 1863, Francis Newman took up the argument in an article entitled "The Reformation Arrested ". "Bibliolatry " was " the critical mistake of the first Reformers ", the " evil legacy » they had left the Church of England. " A religious Reformation, in the very direction to which Colenso points, is demanded, Newman declared, by the most intelligent part of the nation ". Bishop Colenso, speaking for himself while under threat of deposition for his critical views on the Pentateuch, pointed out cooly that in the sixteenth century Cranmer, Ridley, and Latimer, although consecrated as bishops of the Roman Church, " did not resign their sees as soon as they became Protestant bishops ». Anglicans, having based their church structure on one reformation, had no right to declare $a$ priori that there should never be another ${ }^{42}$.

The risk attendant on justifying oneself by appeal to the example of three bishops who, in the event, were burned as heretics, was negligible by the 1860 s. The "Church of the Future ", as Newman called it, had been born. A new faith was rising, phoenix-like, from the ashes of the old faith that had spent itself pursuing the likes of Colenso and the authors of Essays and Reviews ${ }^{43}$. Within the Establishment the Church of the Future and its new faith were weakly represented by clergymen such as Maurice and Stanley. In 1865, Maurice looked forward to « a reformation more complete by far than that of the sixteenth century "; Stanley likewise had no doubt at the time that a " new " or " second Reformation » was being prepared by « the various tendencies

40. Ruth Barton, « Evolution : The Whitworth Gun in Huxley's War for the Liberation of Science from Theology ", in David OLDROYD, Ian LANGHAM, eds, The Wider Domain of Evolutionary Thought, Dordrecht, D. Reidel Publishing Co., 1983, p. 286, n. 122 ; David DE GIUSTINo, Conquest of Mind: Phrenology and Victorian Social Thought, London, Croom Helm, 1975, p. 128-129.

41. [James Anthony Froude], "The Book of Job ", Westminster Review, new series, t. 4, 1853, p. 444 ; Herbert PaUl, The Life of Froude, London, Sir Isaac Pitman \& Sons, 1905 , p. $95-97,103$.

42. [Francis NewMAN], "The Reformation Arrested ", Westminster Review, t. 79, 1863 , p. 392, 393 ; J. W. Colenso, quoted in A. O. J. Cockshut, op. cit. supra n. 39, p. 100 .

43. F. Newman, art. cit. supra n. 42, p. 393 ; J. A. Froude, art. cit. supra n. 41, p. 421 . 
of the age " 44 . But it remained for one whose notion of a viable Establishment was said to resemble their own - it remained for that preacher of " lay sermons " and self-consecrated " bishop » of the " Church scientific », T. H. Huxley, to press the cause of a New Reformation throughout a public career of more than thirty years. From his announcement of the theme in 1860 at the Royal Institution to his extended analysis of Protestant principles in his "Prologue " to Essays on Some Controverted Questions in 1892, Huxley maintained that « a reformation... is waiting to come ", a " wider and deeper change than that effected three centuries ago ", or rather, he explained, " a continuation of that movement $"$. If only people would live in accordance with « that agnostic confession " which makes it immoral to profess knowledge of what cannot be known, this « approximation to the millennium » would arrive ${ }^{45}$.

Huxley's « agnostic confession » never quite amounted to a creed after the manner of the Thirty-nine Articles of the Church of England. When Samuel Laing, the agnostic railway entrepreneur, set down eight agnostic articles to oblige the Anglican prime minister, Gladstone, Huxley denied publicly that agnosticism was a creed. If a creed were to be compulsory, he preferred that of St. Athanasius, the meaning of which, he said, "I have on the whole a clearer conception " ${ }^{46}$. Yet Froude, the devoted biographer of Thomas Carlyle, spoke repeatedly of Carlyle's "Creed " and its influence upon himself and other admirers, such as Huxley. And little wonder. These young men and women, who by upbringing had been habituated to a creed as a vigorous summary of collective belief, who had once recited a creed as an « act of intellectual adoration ", could scarcely have used a better word for those " other forms " of collective belief arising, as Froude put it, from where the " roots » of the old creed were " cut away " 47 . To call one's new con-

44. F. D. MAURICE, The Conflict of Good and Evil in Our Day : Twelve Letters to a Missionary, London, Smith, Elder and Co., 1865, p. 171 ; A. P. Stanley to J. C. Shairp, 1865, in Rowland E. Prothero, The Life and Correspondence of Arthur Penrhyn Stanley.... London, John Murray, 1893, t. 2, p. 239 ; A. P. STANLEY, " The Theology of the Nineteenth Century ", Fraser's Magazine, t. 71, 1865, p. 252-268.

45. T. H. HuXLEY, The Scientific Memoirs of Thomas Henry Huxley, ed. Michael FosTER and E. Ray LANkester, London, Macmillan and Co., 1898-1902, t. 2, p. 393 ; T. H. HuXley, op. cit. supra n. 38, t. 3, p. 191-192; Huxley to his wife, 8 Aug. 1873, in L. HuXLEY, op. cit. supra n. 30, t. 1, p. 397 ; T. H. HuXLEY, op. cit. supra n. 30, t. 5 , p. 40. See Bruce Gordon Murphy, "Thomas Huxley and His New Reformation", Ph. D. dissertation, Northern Illinois University, 1973, and Bernard LiGHTMAN, " Pope Huxley and the Church Agnostic : The Religion of Science ", Historical Papers, 1983, p. 150-163, which takes the analysis further.

46. T. H. HuXLEY, op. cit. supra n. 38, t. 5, p. 245 ; S. LAING, Modern Science and Modern Thought, London, Chapman and Hall, 1895, p. 282-283, 286-287.

47. John TULloch, Movements of Religious Thought in Britain during the Nineteenth Century..., London, Longmans, Green \& Co., 1885, p. 196-197 ; Richard Holt HuTTON, 
victions a creed was to pay them a compliment. A creed united its adherents ; it represented their most deeply felt convictions. To some, pace Huxley, it was a moral necessity. Besides, according to the dissident intellectuals, their old and new convictions were organically linked. To call the new convictions a creed signified that the religious instinct underlying them remained unchanged. For just as the " old creed » was " adapted... to the wants of its believers ", so, it was said, a " new creed " would be adapted to "new social and individual requirements ». The old was " decaying ", the new " growing " in its place. Society must decide, wrote Stephen (recalling his own personal crisis), " which creed... favours the faith which is the other side of energetic conduct "; which gives the " clearest rules » by which to « regulate our lives $" 48$. For rigour and candour of reply, none excelled the high churchmen among the dissident intellectuals, the followers of Auguste Comte. In the five dropsical volumes of his Problems of Life and Mind (1874-1879), Lewes laid the "foundations of a creed " that would « condense our knowledge, guide our researches, and shape our lives ", a creed based on the principles of scientific method. Morley, in his famous essay On Compromise (1874), foresaw that « a new creed by which men can live, ... an expansion, a development, a re-adaptation, of all the moral and spiritual truth that lay hidden under the worn-out forms ", would one day be built by " science ". " Nothing but such a basis, wrote Harrison, can satisfy the mind of the inquirer or give coherence to the social body $"{ }^{49}$.

English religiosity, a Reformed and reforming influence, could safely imbibe its ideology from a critic of revolutionary France. Comte was " the evangelist of the expert ». Positivism, stripped of its magisterium and its liturgy, its catechism and its saints, resembled the creed of the dissident intellectuals at-large. A low church or nonconformist formulary would impart " coherence to the social body " just as well ${ }^{50}$. In Catholic France, Comte had proposed to

Aspects of Religious and Scientific Thought, London, Macmillan and Co., 1899, p. 5 ; J. A. Froude, The Nemesis of Faith, London, John Chapman, 1849, p. 33 ; William KIRKuS, "Morality and Creeds ", Theological Review, t. 4, 1867, p. 541.

48. Leslie StEPHEN, Essays in Freethinking and Plainspeaking, new ed., London, Smith, Elder \& Co., 1907, p. 124, 406 ; ID., An Agnostic's Apology and Other Essays, 2d ed., London, Smith, Elder \& Co., 1903, p. 10, 51 ; H. SPEnCER, An Autobiography, London, Williams \& Norgate, 1904, t. 2, p. 468. See Kingsbury BADGER, "Christianity and Victorian Religious Confessions ", Modern Language Quarterly, 1. 25, 1964, p. 86-101. 49. George Henry LEWES, The Foundations of a Creed, London, Trübner \& Co., 18741875, t. 1, p. 2 ; John MORLEY, On Compromise, 2d ed., London, Chapman and Hall, 1877 , p. 125 ; Frederic HARRison, The Creed of a Layman : Apologia pro Fide Mea, London, Macmillan and Co., 1907, p. 151.

50. N. AnNan, Leslie Stephen : The Godless Victorian, London, Weidenfeld and Nicolson, 1984, p. 195 ; C. KENT, op. cit. supra n. 1, pt. 2. 
" recommence on a better intellectual and social basis the great effort of Catholicism, to bring Western Europe to a social system of peaceful activity and intellectual culture, in which Thought and Action should be subordinated to universal Love $" 51$.

In Protestant England, the dissident intellectuals proposed to recommence on a better intellectual and social basis the great effort of the Protestant Reformation to bring about a social system of personal morality and intellectual freedom. In France the chief inspiration of Comte's proposal had been the revolution of 1848 , which was thought to have ushered in history's " positive " phase with the proclamation of a Republic. In England the dissident intellectuals were similarly inspired by the liberalizing tendencies evoked by Chartism and the Anti-Corn Law League, which commenced in 1846 with the advent of Free Trade. On either hand, in France and in England, among Positivists and dissident intellectuals alike, the emphasis in their social prescriptions fell on continuity, moral authority, and progress. The best aspirations of an earlier religious tradition, they believed, would be better fulfilled by a new professional " priesthood " - the term was Francis Galton's as well as Comte's - who would place progress on a « better intellectual and social basis " with the creed of scientific naturalism 52 .

The Positivist motto, "order and progress ", summed up the theodicy inherent in the naturalistic creed better than the indigenous English slogan, a « New Reformation 》. Progress, according to the dissident intellectuals, was merely the natural order at work; the natural order throughout the living world maintained itself through uniform continuous growth. In reality, therefore, social relations were neither contractual nor conflictive, but vital and organic. "The whole complex frame of society, Froude declared, is a meshwork of duty woven of living fibre, and the condition of it remaining sound is, that every thread of its own free energy shall do what it ought ». Spencer, who in 1860 spelled out the organic doctrine in minute detail, spent the rest of his life developing its ethical implications. This doctrine, which lay at the basis of Comte's sociology, also furnished the premise of the dissident intellectuals' commitment to liberal reform ${ }^{53}$. Natura non facit saltum -

51. Auguste Comte, A General View of Positivism, trans. J. H. Bridges, 2d ed., London, Reeves \& Turner, 1880, p. 67.

52. Ibid., p. 268, 280 ; Francis GALTON, English Men of Science : Their Nature and Nurture, London, Macmillan and Co., 1874, p. 260.

53. J. A. Froude, art. cit. supra n. 41, p. 448 ; H. SPENCER, "The Social Organism ", Westminster Review, new series, t. 17, 1860, p. 90-121. See J. C. GreENE, « Biology and Social Theory in the Nineteenth Century : Auguste Comte and Herbert Spencer $"$, in op. cit. supra n. 16, p. 60-94. 
Nature makes no leaps : society must change gradually. Natura nihil agit frustra - Nature does nothing in vain : society grants to each their appointed task. Gradualism and functionalism in the new theodicy replaced the static teleology of the old. And if the old theodicy had spared industrial England the " red fool-fury of the Seine ", then in a day when the Paris sky again glowed red, the theodicy of a New Reformation could promise nothing less.

«We have been to the brink of the volcano, wrote Stephen of his forebears, and we did not like the glimpses we caught of the seething masses of inflammatory matter at the bottom. The effect was fairly to startle us back into any old creed which led to less disastrous results ".

Just « any old creed », however, did not suffice - Stephen referred no doubt to his own evangelical past - for in order « that a creed may be permanent it must satisfy the intellect $"$. Among the dissident intellectuals, the creed of scientific naturalism filled the bill. W. R. Grove, whose doctrines of the correlation and the continuity of physical forces buttressed the naturalistic creed, spoke their mind when he reminded the British Association for the Advancement of Science that revolutionary ideas and a priori reasoning

« are far more unsound and give us far less ground for improvement of the race than the study of the gradual progressive changes arising from changed circumstances, changed wants, changed habits. Our language, our social institutions, our laws, the constitution of which we are proud, are the growth of time, the product of slow adaptations, resulting from continuous struggles. Happily in this country practical experience has taught us to improve rather than to remodel ; we follow the law of nature and avoid cataclysms $\gg 54$.

But in asserting that an anti-revolutionary creed must " satisfy the intellect " if it is to be " permanent ", Stephen also acknowledged that the first impulse towards its acceptance " comes from the passions". "Therefore, he said, a revival of belief may be due much more to a change in social conditions than to any process of logical conviction ". Stephen wrote better than he knew. The " revival of belief " in which he participated, whatever permanence it derived from the « intellect » and " logical conviction ", owed its existence fundamentally to a " change in social conditions " in Victorian England. Scientific naturalism was

54. L. Stephen, Essays..., op. cit. supra n. 48, p. 145, 147 ; W. R. Grove, « Address of William Robert Grove, Esq., President of the British Association for the Advancement of Science... ", The Correlation of Physical Forces..., Sth ed., London, Longmans, Green, and Co., 1867, p. 346. 
the creed of a movement, as one adherent put it, that had « grown out of the strong impulse given to the moral sense by political freedom $»$. The theodicy of the dissident intellectuals was related organically to the social crisis of their times ${ }^{55}$.

Commenting on the national conceit of Victorian Englishmen, who compared their moral character unfavourably with that of the French, Walter Houghton recalled seeing in one of the stalls along the Seine a book entitled Dieu, est-il-Anglais? The provenance of this book is unknown, but certainly French intellectuals in the nineteenth century might be forgiven for having posed the question. Religion in France had not survived an earlier " crise de conscience " (Hazard) with the tenacity it had in England. Since the Civil Constitution of 1790, and still more after the Napoleonic reforms, the Gallican Church had been tamed and brought to heel. French intellectuals - Comtists notwithstanding could leave their English counterparts to shore up the old " heavenly city " (Becker) with an evolutionary framework, while themselves enjoying a long tradition of alienation from organized religion. Did not English intellectuals consistently duck charges of fomenting « materialism ", "atheism ", and " revolution "? What to them was more important than dissociating themselves from philosophes - Darwin from Lamarck, Huxley from Rousseau, Spencer from Comte ? Genuine anti-clericalism and republicanism did exist in England, but only on the margins of respectability as a proletarian movement. The dominant intellectual culture was pervasively and indelibly religious ${ }^{56}$.

An analogous situation, it might be said, obtains between French and English intellectuals in twentieth-century historiography. Roger Chartier has noted « the inevitable rigidity of a given nation's way of considering historical questions ".

« Each national historiography possesses its own conceptualization, and in each one different ideas enter into play, each indistinguishable from the next to foreign eyes $" 57$.

55. L. STEPHEN, Essays..., op. cit. supra n. 48, p. 147 ; William Kingdon ClifFORD, Lectures and Essays, ed. L. STEPHEN and Frederick Pollock, London, Macmillan and Co., 1879, t. 2, p. 250.

56. See E. RoYLE, Victorian Infidels: The Origins of the British Secularist Movement, 1791-1866, Manchester, Manchester University Press, 1974 and ID., op. cit. supra n. 33.

57. Roger CHARTIER, " Intellectual History or Sociocultural History ? The French Trajectories ", in Dominick LACAPRA, Steven L. KAPLAN, eds, Modern European Intellectual History : Reappraisals and Perspectives, Ithaca (NY), Cornell University Press, 1982, p. 14. 
French historians, on reading the preceding pages, may thus be forgiven for posing the question, "L'histoire intellectuelle est-elle anglaise ? " For surely the English protest against an intellectual history of abstractions, of disincarnate minds, of free-floating systems of thought, disjoined from the social conditions that authorized their production, was instituted more than half a century ago by Lucien Febvre and the first generation of the Annales ? And where, pray, is evidence of the subtle and disciplined analysis of unconsciously shared assumptions, feelings, mentalites - an analysis, one would have thought, peculiarly suited to the subject of a " crisis of faith " - that has been practised by a succession of distinguished French historians over the past twenty-five years? Does not a thesis in the social history of ideas risk both sociological reductionism and reification of the thoughts of social agents - a challenge that French intellectual historians have had to heed ? And, finally, why is there no acknowledgement of the historical epistemologies of Gaston Bachelard and Georges Canguilhem, which would seem relevant to analyzing any critical transformation or rupture of theodicies in Victorian England ?; why no reference to the archéologie of Michel Foucault ? English-speaking intellectual historians, in their eclecticism and empiricism, have only begun to treat their Victorian crisis in depth. Historiographically, they stand every chance of reinventing the wheel ${ }^{58}$.

It would be false and frankly self-conceited of interpreters of the Victorian crisis simply to shrug off these (hypothetical) remarks. Nowhere is the insularity of English scholarship more clearly evinced than in its atheoretical devotion to "common sense ». American scholars, in the rush for academic tenure, tend to be pragmatists besides. A recent reference to "Foucault and other members of the Dadaist school of philosophy " by a prominent intellectual historian and member of the English establishment may strike French colleagues as arrogant and obscurantist ${ }^{59}$, but in mitigation one should plead the sad reality of a linguistic barrier, which makes French scholarship inaccessible to some, and the lack of specialized training in the problems and procedures of intellectual history, which handicaps many in the field. The present author, for example, came to the social history of ideas via ecclesiastical history (narrowly conceived) and the history of science. Others have followed a similar route, including several of the historians of science referred to above who have entertained or contributed revisionist views on topics connected with the "Victorian crisis of faith ". Historio-

58. Chartier's analysis (ibid.) has suggested this line of interrogation.

59. N. ANNAN, op. cit. supra n. 50, p. 195. 
graphy and historical research on this subject will no doubt proceed instep, a kind of "theoretical-practice " that may strike outsiders as muddled or muddleheaded. But English-speaking scholarship has its own training, its own audiences, and its own conventions of debate. National traditions are, as Chartier says, inevitably rigid, although there may be hope for convergence, if not rapid change.

In 1982 Chartier noted that French intellectual historians had begun to pose the problem of the relationship of ideologies and society " in terms of articulations between intellectual choices and social position on the scale of well-defined segments of society or even on the scale of the individual $»$. He concluded his survey of French historiographic traditions by calling for intellectual history to " come out of its ghetto " and enter into dialogue with « neighbouring social sciences » such as ethnology and sociology 60 . Here at least the convergence of interests between certain French and English-speaking intellectual historians is striking, for in the same year Steven Shapin published his masterly review, " History of Science and Its Sociological Reconstructions ", which demonstrated the very considerable empirical achievements of British and American scholars working in the historical sociology of scientific knowledge ${ }^{61}$. The article affords numerous examples of investigation on the " reduced scale " described by Chartier, including studies with a genuine claim to interdisciplinary sophistication. Works by Adrian Desmond, John Durant, Leon Jacyna, Martin Rudwick, and James Secord have special relevance for interpreting the Victorian crisis, and Shapin's bibliography is by no means complete. Among publications of the 1970 s one need only mention the works of Morris Berman and the graceful essays collected in Nature and the Victorian Imagination ${ }^{62}$. Since 1982 Desmond and Rudwick have contributed importantly to this literature, Roger Cooter has fulfilled the promise of earlier research, and the socalled Darwin Industry has achieved new levels of productivity, auguring still greater output with the Calendar of Darwin letters and the first volume of The Correspondence of Charles Darwin ${ }^{63}$. Although

60. R. Chartier, op. cit. supra n. 57, p. 32, 42.

61. Steven SHAPIN, "History of Science and Its Sociological Reconstructions ", History of Science, t. 20, 1982, p. 157-211.

62. Morris BERMAN, "Hegemony" and the Amateur Tradition in British Science ", Journal of Social History, t. 8, 1974-1975, p. 30-50 ; ID., Social Change and Scientific Organization: The Royal Institution, 1799-1844, London, Heinemann Educational Books, 1978 ; U. C. KNOEPflMACHER, G. B. Tennyson, eds, Nature and the Victorian Imagination, Berkeley, University of California Press, 1977.

63. Adrian DESMOND, "Interpreting the Origin of Mammals : New Approaches to the History of Paleontology ", Zoological Journal of the Linnean Society, t. 82, 1984, p. 7. 16 ; ID., " Robert E. Grant : The Social Predicament of a Pre-Darwinian Transmutationist ", Journal of the History of Biology, t. 17, 1984, p. 189-223 ; ID., “ Richard Owen's 
English-speaking historians will probably continue to answer questions such as « Le darwinisme social existe-t-il ? " after the manner of Bacon rather than Descartes, it is to be hoped that a subject so important as Darwin's life and work, which may take the Victorian crisis as its frame of reference, will provide the common ground for intellectual historians of many traditions to achieve mutual understanding ${ }^{64}$.

James R. MOORE, The Open University Milton Keynes, England.

Reaction to Transmutation in the 1830's ", British Journal for the History of Science, t. 18, 1985, p. 25-50 ; ID., The Politics of Evolution: Social Change and the Structure of Comparative Anatomy in the 1830s, Chicago, University of Chicago Press, 1986 ; Martin J. S. RuDwICK, "Charles Darwin in London: The Integration of Public and Private Science ", Isis, t. 73, 1982, p. 186-206 ; ID., The Great Devonian Controversy : The Shaping of Scientific Knowledge among Gentlemanly Specialists, Chicago, University of Chicago Press, 1985 ; Roger CoOTER, The Cultural Meaning of Popular Science : Phrenology and the Organization of Consent in Nineteenth Century Britain, Cambridge, Cambridge University Press, 1985 ; David KoHN, ed., The Darwinian Heritage, Princeton (NJ), Princeton University Press, 1985 ; Frederick BurkhaRdT, Sydney Smith et al., eds, A Calendar of the Correspondence of Charles Darwin, 1821-1882, New York, Garland Publishing, 1985 ; ID., eds, The Correspondence of Charles Darwin, Cambridge, Cambridge University Press, 1985, t. 1, 1821-1836. For reviews of the recent Darwin literature, see J. R. Moore, « On Revolutionizing the Darwin Industry : A Centennial Retrospect ", Radical Philosophy, 37, 1984, p. 13-22 and ID., "Darwin's Genesis and Revelations ", Isis, t. 76, 1985, p. 570-580.

64. Yvette Conry, « Le darwinisme social existe-t-il ? », Raison Présente, t. 66, 1983, p. 17-39. Although Darwin has no satisfactory biography, other biographical works have recently appeared that situate their subjects in relation to the Victorian crisis. See N. ANnAN, op. cit. supra n. 50 ; James A. ColalACo, James Fitzjames Stephen and the Crisis of Victorian Thought, New York, St. Martin's Press, 1983 ; Sally SHuTtLeworth, George Eliot and Nineteenth-Century Science : The Make-Believe of a Beginning, Cambridge, Cambridge University Press, 1984 ; and Martha S. VOGELER, Frederic Harrison : The Vocations of a Positivist, Oxford, Clarendon Press, 1984. 